\title{
Equal Outcomes, but Different Treatment - Subtle Discrimination in Email Responses From a Correspondence Test in Switzerland ${ }^{1}$
}

\author{
Eva Zschirnt*
}

\begin{abstract}
Correspondence tests on discrimination usually report only whether an applicant was invited for a job interview or not. Yet, data from a field experiment in Switzerland demonstrate that candidates with the same outcome are not necessarily treated equally. The paper complements correspondence test results with information on the time elapsed until candidates were contacted, as well as qualitative differences in invitation or rejection emails. Keywords: correspondence test, Switzerland, labour market, subtle discrimination

\section{Gleiche Ergebnisse, aber unterschiedliche Behandlung - subtile Diskriminierung bei E-Mail-Antworten aus einem Korrespondenztest in der Schweiz}

Zusammenfassung: Korrespondenztests zeigen in der Regel nur, ob ein Bewerber zu einem Vorstellungsgespräch eingeladen wurde oder nicht. Daten aus einem Schweizer Feldexperiment zeigen jedoch, dass Kandidaten mit dem gleichen Ergebnis nicht unbedingt gleich behandelt werden. Dieser Artikel ergänzt die Ergebnisse des Korrespondenztests mit Informationen über die Zeit bis zur Kontaktaufnahme mit den Kandidaten sowie mit qualitativen Unterschieden in den Einladungs- oder Ablehnungs-E-Mails.

Schlüsselwörter: Korrespondenztest, Schweiz, Arbeitsmarkt, subtile Diskriminierung

\section{Des résultats égaux, mais un traitement différent - discrimination subtile dans les réponses par courriel dans un test par correspondance en Suisse}

Résumé: Les tests par correspondance se limitent généralement à indiquer si un candidat a été invité à un entretien d'embauche ou non. Pourtant, les données d'une expérience suisse montrent que les candidats avec le même résultat final ne sont pas nécessairement traités de manière égale. L'article complète les résultats du test par correspondance avec des informations sur le temps écoulé jusqu'au moment où les candidats sont contactés, ainsi que sur les différences qualitatives dans les courriels d'invitation ou de rejet.

Mots clés: test par correspondance, Suisse, marché du travail, discrimination subtile

European University Institute, Department of Political and Social Sciences, 50014 San Domenico di Fiesole, Italy, eva.zschirnt@eui.eu.

1 This research was supported by the nccr - on the move funded by the Swiss National Science Foundation. I would like to thank Daniel Auer, Rosita Fibbi, Carolin Fischer, Fabienne Liechti and Didier Ruedin as well as the two anonymous reviewers for their comments. 
In recent years there has been an increase in field experiments on ethnic or racial discrimination in the labour market (Bertrand and Duflo 2017; Neumark 2018; Riach and Rich 2002; Rich 2014). In these field experiments researchers present real employers with fictitious candidates applying for advertised positions either in person, on the phone, or in writing. Candidates differ only in the characteristics that are the focus of the study (e.g. ethnicity) and differences in invitation rates can then be attributed to discriminatory treatment in the hiring process. A metaanalysis by Zschirnt and Ruedin (2016) has shown that ethnic minority candidates have to write about 1.6 times as many applications to be invited for a job interview. However, field experiments focus on the final outcome alone, whether applicants were invited for a job interview or not. It is assumed that in cases where both candidates were invited or rejected, they were both treated equally. While the outcome might - eventually - be the same, it is nevertheless possible to observe differences in the treatment of applicants. These differences, for example the tone of the correspondence or the length of time until a reply was received, are, however, not usually discussed.

There are only a few studies that address these subtle forms of discrimination. These were mostly in-person audit studies where the testers were able to observe treatment during the job interview. So far, there exists just one example of a correspondence test analysing email responses for subtle discrimination: on the US housing market (Hanson et al. 2011). Correspondence tests on hiring discrimination published in recent years have not usually made use of the information that email responses in particular provide (Crabtree 2018). The only aspect addressed in addition to the correspondence test results is the time difference relating to when applicants were contacted (Kaas and Manger 2012; Weichselbaumer 2016). Looking at employers' responses to paired application side by side therefore enables us to consider not only the outcome of the application procedure, but also to look at the subtle discrimination revealed in emails.

This paper uses results from a recent Swiss correspondence test (Zschirnt 2019). It compares the results of the field experiment with the way applicants were contacted by employers. Focusing on the timing of responses and the content of the emails that candidates received, I show that the simplification of correspondence test results happens at the expense of a more nuanced picture.

\section{Theory}

Research on labour market discrimination, in particular on the grounds of race and ethnicity, has a long tradition, specifically in economics and sociology. This 
literature often focuses on two classical economic theories to explain why discrimination occurs at the interpersonal level ${ }^{2}$ : the theory of taste-based discrimination (Becker 1957) and the theory of statistical discrimination (Phelps 1972; Arrow 1973; Aigner and Cain 1977). Becker's theory departs from the assumption that people (e. g. employers) have a certain distaste for working with a particular group (e.g. migrants or women) and are willing to pay a price (e.g. a higher salary to another candidate) to avoid hiring members of this disliked group. Statistical discrimination theory, however, assumes that employers act in a way to maximise profits and resort to discriminatory hiring behaviour to make up for a lack of information about an applicant. Thus, they use group membership as a proxy to compensate for this missing information. While both theories are very prominent in the academic debate, they fail to explain why discrimination still occurs at persistent levels over time and place. Both theories predict that discrimination should disappear or at least decline over time, either because discriminating employers go out of business (taste-based discrimination) or because employers receive more information about different groups the better they become known and thus no longer feel the need to infer information based on group signals (statistical discrimination) (e. g. Darity and Mason 1998). Yet, meta-analyses of field experiments have shown that discrimination rates remain quite stable over time (Zschirnt and Ruedin 2016; with a focus on the US Quillian et al. 2017).

Apart from these two well-known economic theories researchers in other fields, such as sociology and social psychology, have developed alternative explanations for the occurrence of discriminatory treatment. One approach focuses on subtle discrimination. Research on subtle discrimination in the work place or on work place incivility has been advanced mostly in the field of social psychology (for the case of Switzerland see e. g. Krings et al. 2014), for example Van Laer and Janssens (2011) define subtle discrimination as ...

... forms of discrimination that pervade society, are less visible, often very ambiguous for those experiencing it, not easily recognized as discrimination and often not punishable under anti-discrimination legislation. It entails interpersonal discrimination that is often enacted unconsciously or unintentionally and that is entrenched in common, everyday interactions, taking the shape of harassment, jokes, incivility, avoidance and other types of disrespectful treatment. (Van Laer and Janssens 2011, 1205)

While the acts might seem unimportant at first glance, Rowe argues that "these mechanisms of prejudice against persons of difference are usually small in nature, but not trivial in effect. They are especially powerful taken together" $(1990,153)$, thus alluding to the concept of cumulative discrimination (Blank et al. 2004).

2 For a detailed discussion on the causes of discrimination see Pager and Shepherd (2008) or Reskin (2003). 
Similarly, Krings et al. (2014) have shown that immigrants experience instances of subtle discrimination or workplace incivility. In their findings, groups that are believed to integrate easily because they are competitive and from neighbouring countries experience "seemingly harmless discourteous behaviours" (Krings et al. 2014, 497). The possibility of cumulative effects of discriminatory treatment (apart from being invited to a job interview or not) are discussed, for example, in Bendick, who points out that "taken together, these effects make the labour market experience of identically-qualified minority and majority job applicants profoundly different" $(1996,29)$. Thus, even behaviour that is often unconscious and unintentional can constitute subtle discrimination and can have harmful and cumulative long-term effects.

\section{Background}

Since the late 1960s, researchers have attempted to measure ethnic and racial discrimination in hiring decisions using field experiments (Daniel 1968). Since then, the methodology has evolved considerably (Riach and Rich 2002; Rich 2014; Zschirnt 2016; Bertrand and Duflo 2017; Neumark 2018). Furthermore, meta-analyses have shown that ethnic or racial minority job candidates encounter discrimination in all the countries studied (Zschirnt and Ruedin 2016) and that discrimination rates remain stable over time (ibid; for the US in particular Quillian et al. 2017).

While most research on hiring discrimination focuses on the observable differences in invitation rates for minority and majority candidates, it is also possible to observe more subtle forms of discrimination. It has been shown that the data collected in a field experiment can be used for more than just the analysis of the outcome; that is, whether applicants received a call-back for a position or not. Riach and Rich (2002) already mention that some of the experimental studies discussed in their paper recorded differences in treatment, despite equal outcomes in the application process, quoting the Fair Employment Commission's (FEC) and Urban Institute (UI) studies in the US or the International Labour Organisation (ILO) studies in Europe. Summarising these US studies, Bendick (1996) includes examples of discriminatory behaviour that had been observed in the tests, e. g. being invited for an interview, receiving a job offer or a referral, the compensation offered, being steered into certain positions, being offered alternative opportunities, and the cumulative effect of these forms of differential treatment. However, so far, such instances of differential treatment have been observed mostly in in-person audit studies (e. g. Bendick et al. 1991; Bendick 1996; Lodder et al. 2003; Pager et al. 2009; Bendick et al. 2010; Ghumman and Ryan 2013). Information that was recorded included the length of phone calls or interviews, where and by whom the interview was conducted, the number of topics discussed, the differences in compensation, 
hours or shifts offered, if information about the job duties was offered without being asked, how politely applicants were treated, if additional vacancies were mentioned, or if applicants were steered towards other positions.

Looking, for example, at the in-person audit study by Pager et al. (2009), the results from the field experiment are complemented with testers' observations on the differences in treatment. While the experimental results show the importance of race in hiring, analysing these field notes provides a more nuanced picture. They group their observations of employers' responses into three categories: (1) a categorical exclusion of the minority candidate, (2) shifting standards where "employers' evaluations of applicants appear actively shaped or constructed through a racial lens" (Pager et al. 2009, 787), and (3) race-coded job channelling, where candidates are channelled into certain job types. They argue that their descriptive results "[reveal] mechanisms at work that observational research can rarely identify" (Pager et al. 2009, 787). Even in cases that are recorded as equal treatment in the results presented in the field experiment, discriminatory mechanisms can be at play.

Equally detailed information on the more nuanced aspects of the application process is usually missing in written field experiments. I am aware of only one correspondence test on the US housing market, where email correspondence with landlords was analysed for subtle discrimination (Hanson et al. 2011). While the ILO project on labour market discrimination included information on equal but different treatment, this applied mostly to the telephone contact stage (Bovenkerk et al. 1995; de Prada et al. 1995; Goldberg et al. 1995; Arrijn et al. 1998; Attström 2007; Cediey and Foroni 2008)3. In their study on the Netherlands Bovenkerk et al. emphasised that ...

... although the evidence of discrimination in these instances is less "hard" than the difference between acceptance and rejection (unequal treatment), it is important in practice. Equal but different treatment does not deny one the opportunity to compete for the job, but may be clearly discouraging for the applicant. (Bovenkerk et al. 1995, 12)

Thus, like the other ILO studies, Bovenkerk et al. provide information about the cases where equal but different treatment occurred.

Looking at studies conducted since 2000, Rich (2014) addresses instances of "other dimensions of differential treatment" or "dishonest concealment of rejection" and identifies them both on the labour and the housing market. For the former, she refers particularly to Pager et al. (2009), discussed above, and Drydakis and Vlassis (2010) who showed differences in wages and insurance coverage offered to applicants. Not discussed in Rich (2014) is Gaddis (2015) who included information from forwarded emails that had accidently also been sent to applicants. Furthermore, both Kaas and Manger (2012) and Weichselbaumer (2016) provide information about

3 Although not part of the ILO project Fibbi et al. (2003) followed the same approach. 
the time interval in which candidates were contacted. As Weichselbaumer points out, "migrants are not only discriminated with respect to the frequency with which they are invited for an interview, they also receive these invitations more hesitantly" $(2016,26)$. Not only are they less likely to be invited for a job interview, they also have to wait longer for an invitation.

These small differences in treatment are difficult to observe, unless cases are regarded side by side, and these instances of "equal but different treatment" as they were called in the ILO studies or "subtle discrimination" by Hanson et al. (2011) are observed not only in the hiring process but throughout a person's working life.

\section{Methods}

To address this gap in research, this paper uses data from a recent correspondence test in the German speaking area of Switzerland. It studied hiring discrimination against equally qualified German, Kosovar, and Turkish candidates using a matched pair design. ${ }^{4}$

Ethnicity was signalled by the name, information on citizenship, and listing additional mother languages on the $\mathrm{CV}$ where applicable. As is customary in Switzerland, applicants also include their citizenship on their CV; minority candidates listed dual citizenship. Furthermore, Turkish and Kosovar candidates mentioned their respective languages as a second mother tongue. Finally, all education and work experience listed in the CV had been obtained in Switzerland.

Vacancies for two positions, requiring a completed apprenticeship as a sales assistant (Detailhandelskauffraul-mann) and electrician (Elektroinstallateur), and two intermediately skilled positions as a nurse (Pflegefachfrau), and HR clerk (HR Fachmann/-frau) were obtained from internet job boards. Application material, which in Switzerland includes not only a cover letter and CV, but also work certificates and diplomas, was carefully constructed and discussed with HR specialists. For the final required element, a photograph, we received the permission from Doris Weichselbaumer to use photographs she had carefully prepared and pretested for her Austrian correspondence test (Weichselbaumer 2016). The individual parts of the application materials (CV, cover letter, photo, etc.) were randomly assigned to the candidates. The paired applications were then sent online. Responses were received by email and mobile phone and carefully recorded; invitations for job interviews were quickly and politely declined by email.

While correspondence testing allows researchers to observe real life hiring decisions, it also faces limitations, one of them being that only advertised positions can be included in the experiment (Heckman and Siegelman 1993). If positions are

$4 \quad$ Details of the research design are provided in Zschirnt (2019), which discusses the quantitative results of the field experiment. 
filled using word of mouth or personal networks this is likely to be a disadvantage for job-seekers with a migrant background.

For this paper, the time span between sending an application and receiving the first reply by phone or email was measured in workdays and then analysed by duration until a rejection or invitation was received. In a second step, only responses received by email were considered when analysing content for signs of subtle discrimination.

\section{Results}

This section briefly presents and discusses the correspondence test results, i.e. the descriptive statistics as customarily displayed. It combines these findings with information on the time when candidates were contacted and examples of the content of email responses.

\subsection{Results from the correspondence test}

Focusing on the German speaking part of Switzerland and the positions of electrician and sales assistant, from October 2017 to March 2018 paired applications were sent to 136 positions for an electrician and 136 positions for a sales assistant, i.e. 544 individual applications. For both of these occupations, vacancies usually mentioned that customer contact was part of the position. In 204 of these 272 application procedures both candidates received a response from the employer, in 31 cases only one applicant received a reply and in 37 cases employers did not react to either candidate. ${ }^{5}$

Considering the 31 cases in which only one applicant was contacted by the employer, while the second applicant received no reaction, in 15 cases the majority candidate was invited for a job interview compared to three invitations for the minority candidate. In 13 cases only one candidate received a rejection email, while the other candidate was not contacted, although there is no clear pattern here; in 6 of these cases the Swiss candidates received no reply and in 7 cases the minority candidate was not contacted.

The correspondence test results presented in Table 1 show that minority candidates in positions requiring a completed apprenticeship have to write 1.23 times as many applications to be invited for a job interview compared to majority candidates (significant at the 5\% level). The relative call back rate is lower for the electricians than for the sales positions (1.12 and 1.48 respectively, both significant at the $5 \%$ level) and also varies by ethnic background.

While German candidates for sales positions show a high relative call back rate of 1.8 (significant at 5\%) for the sales positions, they are treated equally when

5 A more detailed discussion of the quantitative results of this correspondence test is provided in Zschirnt (2019). 
Table 1

Correspondence Test Results from the Swiss (German) Labour Market

\begin{tabular}{|c|c|c|c|c|c|c|c|c|c|c|c|}
\hline & $\begin{array}{l}\text { Number } \\
\text { of jobs }\end{array}$ & $\begin{array}{l}\text { None } \\
\text { invited }\end{array}$ & $\begin{array}{l}\text { Both } \\
\text { invited }\end{array}$ & $\begin{array}{c}\text { Only } \\
\text { majority } \\
\text { invited }\end{array}$ & $\begin{array}{l}\text { Only } \\
\text { minority } \\
\text { invited }\end{array}$ & $\begin{array}{c}\text { Net } \\
\text { discrimination } \\
\text { rate } \%\end{array}$ & $\begin{array}{l}\% \text { call } \\
\text { back } \\
\text { majority }\end{array}$ & $\begin{array}{l}\% \text { call } \\
\text { back } \\
\text { minority }\end{array}$ & Ratio & $\begin{array}{l}\text { Percentage } \\
\text { difference }\end{array}$ & $\begin{array}{c}\text { Chi-square } \\
\text { test }\end{array}$ \\
\hline & [1] & [2] & [3] & [4] & [5] & [6] & [7] & [8] & [9] & [10] & [11] \\
\hline $\begin{array}{l}\text { Sales } \\
\text { assistants }\end{array}$ & 136 & 83 & 19 & 24 & 10 & 26.42 & 31.62 & 21.32 & 1.48 & 10.30 & $0.0164^{* *}$ \\
\hline Germany & 45 & 24 & 7 & 11 & 3 & 38.10 & 40.00 & 22.22 & 1.80 & 17.78 & $0.0325^{* *}$ \\
\hline Kosovo & 46 & 28 & 8 & 7 & 3 & 22.22 & 32.61 & 23.91 & 1.36 & 8.70 & 0.2059 \\
\hline Turkey & 45 & 31 & 4 & 6 & 4 & 14.29 & 22.22 & 17.78 & 1.25 & 4.44 & 0.5271 \\
\hline Electrician & 136 & 56 & 64 & 12 & 4 & 10.00 & 55.88 & 50.00 & 1.12 & 5.88 & $0.0455^{* *}$ \\
\hline Germany & 45 & 16 & 23 & 3 & 3 & 0.00 & 57.78 & 57.78 & 1.00 & 0.00 & 1.0000 \\
\hline Kosovo & 46 & 16 & 23 & 6 & 1 & 16.67 & 63.04 & 52.17 & 1.21 & 10.87 & $0.0588^{*}$ \\
\hline Turkey & 45 & 24 & 18 & 3 & 0 & 14.29 & 46.67 & 40.00 & 1.17 & 6.67 & $0.0833^{*}$ \\
\hline Total & 272 & 139 & 83 & 36 & 14 & 16.54 & 43.75 & 35.66 & 1.23 & 8.09 & $0.0019^{\star * *}$ \\
\hline
\end{tabular}

Chi square test: significant at ${ }^{*} 10 \%,{ }^{* *} 5 \%$, ${ }^{* *} 1 \%$ level.

applying as electricians (relative call back rate of 1.0, not significant). The high discrimination rate against Germans in sales positions is somewhat surprising. Although German named candidates (like all non-Swiss named candidates) indicate that they are dual nationals and that all their schooling had been completed in Switzerland, one possible explanation could be that Swiss German employers expect that these candidates will not be fluent in the local dialect and anticipate that this would be unacceptable to their customers. This high relative call back rate is in line with attitude research conducted by Helbling (2011) in Zurich where he found strong anti-German attitudes. Turkish candidates fare better than candidates from Kosovo in both occupations (relative call back rates: Turkish electricians 1.17, Turkish sales assistants 1.25, Kosovar electricians 1.21, Kosovar sales assistants 1.36, not significant for sales assistants, significant at $10 \%$ for electricians). Because of the lower overall success rate for sales assistants, these results are statistically significant only for the position of electrician.

Overall, the differences by ethnicity mirror findings from attitude research conducted in Switzerland, where immigrants from the Balkans and former Yugoslavia are usually the least liked group in Switzerland, those from Turkey being regarded slightly more favourably and immigrants from EU countries and neighbouring countries are mostly accepted (e. g. Raymann 2003; Helbling 2011; Ruedin et al. 2013; Longchamp et al. 2014; Rapp 2015). There are also differences in the discrimination rate by ethnic groups and occupations studied. The two biggest extremes were observed for German candidates, who are treated equally to their native Swiss peers when applying for positions as electricians, but face the highest rates of discrimination measured in this correspondence test when applying for sales positions. Turkish candidates face discrimination in both occupations, while 
Kosovar candidates are the most discriminated against for positions as electricians and fare worse than Turkish candidates for sales positions.

\subsection{Timing of Responses}

As discussed above, correspondence tests usually stop at reporting these results, i. e. whether an applicant was invited for a job interview or not. However, both Kaas and Manger (2012) and Weichselbaumer (2016) reported that the time when candidates received a reply from the employer varied according to the candidate's background. Looking at the Swiss case the results do not show a clear pattern, except that Kosovar candidates have to wait the longest before receiving a reply (either invitation or rejection).

Figure $1 \quad$ Working days until response

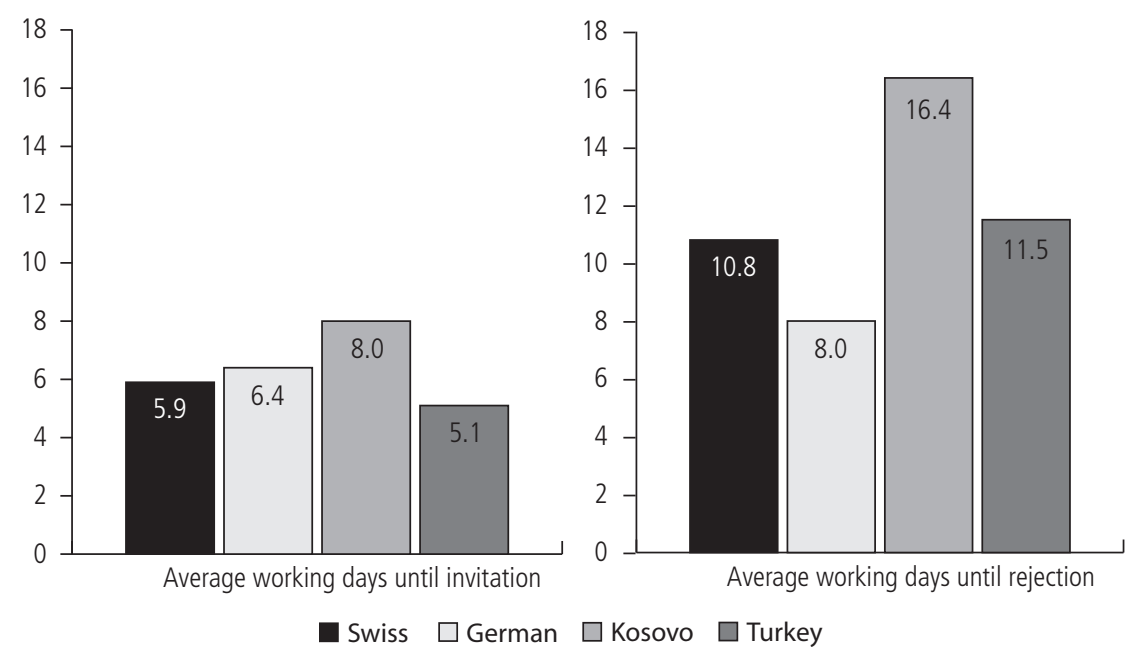

\subsection{Content of Email Responses}

In 112 of 145 cases in which both candidates were contacted by email, messages were the same or very similar. Yet, in the rest of the responses messages differ regarding the names and salutations used, the level of enthusiasm about candidates, keeping applicants in the candidate pool, or blatantly preferring the Swiss candidate. These differences in treatment are shown here with examples from the replies ${ }^{6}$ for both the majority and the minority candidates juxtaposed with each other.

6 Own translations from German to English. Translations were kept as close to the German original as possible. Some replies were unusual, even in the original German version. 
Table 2 Email Responses

\begin{tabular}{lr}
\hline Cases with at least one email response & 194 \\
Only majority contacted & 26 \\
Only minority contacted & 23 \\
& 145 \\
Both contacted & 100 \\
Exactly the same text & 12 \\
Almost the same or very similar texts & 33 \\
Different texts & 16 \\
a) Equal outcome & 17 \\
b) Different outcome & \\
\hline
\end{tabular}

Starting at the top of the body of the email, the salutation line is the first place where unequal treatment occurs. Here we observed misspelled names only once for the majority candidate (Kählin instead of Kälin), but more frequently for the minority candidate (e. g. Hofmann instead of Hoffmann; Krasnigi instead of Krasniqi); using the wrong gender ( «sehr geehrte Herr Hoffmann», although these instances might be cases of typos); confusing first and last names (Mr. Cem, instead of Mr. Yilmaz); or greeting minority candidates with the first and last name, while only the last name is used for Swiss candidates (Dear Ms. Kaelin vs. Dear Ms. Shpresa Krasniqi). Using both the first and last name in the salutation is less formal than using the last name alone and this occurs in the case of Kosovar candidates in particular. This could be a reflection of uncertainty about the given and the family name. While the mistakes about spelling and/or confusing first and last names might be due to employers being less familiar with non-Swiss names, the names chosen were among the most frequent names in these migrant populations and in particular the Turkish and Kosovar names should be easily identifiable and familiar to Swiss employers. There were also cases where no greeting was used for the minority candidate ("Krasniqi" vs. "Dear Mr. Kaelin"), which is unusual and rude in German business correspondence. Finally, we observed two instances where the Swiss candidate was greeted with

Table 3

Problems with Names

\begin{tabular}{l|c|c}
\hline Problem & Majority & Minority \\
\hline First and last names used in greeting & 0 & 2 \\
Misspelled name & 1 & 4 \\
No name in greeting & 3 & 5 \\
Wrong gender & 1 & 2 \\
Total & 5 & 13 \\
\hline
\end{tabular}


"Grüezi», a rather informal greeting in the Swiss German dialect, while the minority candidate was greeted with the polite high-German «Guten Tag».

\subsubsection{Cases with Equal Outcomes}

In several cases both applicants were treated equally regarding the final outcome of their application (i. e. both invited/both rejected), but employers replied more favourably to the majority candidate. This first example shows differences in rejection emails for the same position:

Dear Mr. Kälin, We thank you for your interest in our company and for sending in your application and introducing yourself. Unfortunately, we have to reject your application today, but we have taken the liberty of making a copy of your application, because we might be interested in you at a later date. (0053, Swiss male)

Dear Mr. Yilmaz, We thank you for your interest in our company and for your application. After thorough examination of your application we are sorry to inform you that we cannot consider your application for the vacant position. Please do not feel discouraged, your application has made a very good impression on us, and we therefore believe that you will surely succeed in finding your desired job. (...) (0053, Turkish male)

Both candidates were rejected, but only the Swiss candidate was told that his application would be kept for a possible later opportunity, while the Turkish candidate received a polite, standard rejection message.

A second example also shows the same outcome (rejection) for both applicants, but there were considerable differences in the timing of the replies:

Dear Mr Yilmaz, You have entered your application into the race for the position of (...). We thank you for your interest in our company and the work you put into your application. As promised we are contacting you after having carefully reviewed all the applications we received and having made a first selection. We would have preferred to send you a positive message today, but unfortunately the competition was too strong this time. Other applicants were more convincing for us. (...) (0071, Turkish male)

Dear Mr Kälin, We are referring to your application of (...) and would like to give you a short update. (...) Thanks to you and the other applicants, we are in the fortunate position of holding many excellent applications in our hands after a first selection round. Your application has left a good impression and is still on our reserve list. However, in the first round we preferred other candidates whose applications convinced us even more. (...) and we would like to wait for the results of the first round of interviews and keep your application pending and thoroughly review it again following the first 
interviews. This will be early January. Do you agree? And will you give us a second chance? (0071, Swiss male)

Both candidates were contacted on the same day, the Turkish candidate was immediately told that his application did not make it into the next selection round, while the Swiss candidate was kept in the running. Although the Swiss candidate was rejected a month later, he was encouraged to keep up with their social media channels and to apply again as they are "convinced that you always meet twice in your life - at least”.

The third example of equal outcomes (invitation) shows different levels of enthusiasm about the respective candidates. The day after the applications were sent, the candidates received the following reply:

Grüezi Mr Kälin, I was very pleased and curious about your application. I would be glad if we could meet for an interview. Can you offer me some dates? (0232, Swiss male)

Grüezi Mr Hoffmann, Thank you for your application, we will examine it as soon as possible and inform you about our decision. (0232, German male)

The Swiss candidate was immediately invited for a job interview and was met with very positive feedback on his application, while the German candidate received a standard message that his application had been received. Although he was invited for an interview two days later, the invitation lacked the same level of interest.

In the final example of an application that is shown as "equal treatment" in the correspondence test results, the employer tried very hard to invite the Swiss candidate for an interview. Both candidates sent their application on the same day, but only the Swiss candidate's application was acknowledged. After eleven days, the Swiss candidate received an interview invitation by email and phone message. When the invitation was quickly and politely declined by email saying that the applicant had already found a new position, he immediately received a reply wishing him all the best for the new position, and offering that: "if [this new position] does not suit you and you would look for another opportunity again, please feel free contact us again. We have interesting opportunities ..." (0136, Swiss). Three days after this exchange and 18 days after the application, the German candidate was informed that the preselection of candidates was still ongoing and was asked for patience. After 23 days the German candidate received an invitation by phone.

\subsubsection{Cases with Different Outcomes}

We also observe an obvious preference for the Swiss candidate in cases with different outcomes. While the German applicant in this case received a standardised rejection email, the employer made an effort to meet the Swiss candidate for a job interview: 
Dear Ms Kaelin, We are contacting you a little later than promised ... Apologies! Your application has raised our interest and we would like to meet you. Bern and (...) are unfortunately not near each other. I will be in Bern on (...) to visit the Zwiebel Märit with my wife. If you are still interested in this job (...), we could meet in the early afternoon somewhere close to the train station. I am looking forward to hearing from you. (0127, Swiss female)

The most striking response observed during the correspondence test also occurred in a pair of applications with different outcomes. While the German candidate was never contacted, the Swiss candidate immediately received a long email, which included the employer's mobile phone number and the explicit instruction to call, even in the evening:

Dear Mr. Kälin

Thank you very much for your application (...). I have just looked at it and have come across a few interesting points.

I like your educational background (secondary school and vocational degree), and your experience in service work. Of course, and you are probably well aware of this yourself, I also like your age and your origin. Your move to our area is also very exciting and I can highly recommend this from personal experience ;-)...

I would like to interview you in person and take the opportunity to introduce myself in detail. Already in advance, I can tell you about some very interesting upcoming projects and, moreover, I am convinced that we are an above-average competent and motivated young team with a correspondingly demanding client base.

I am interested in a long-term cooperation and therefore an unlimited contract.

I would appreciate it if you could get back to me with a suggestion for a time for an interview (it can also be in the evening). You can reach me under (...) $(0055$, Swiss male)

Apart from the last two examples, the messages quoted above have shown that cases considered as equal treatment in a correspondence test can be cases of subtle discrimination. These may be comparably minor differences, such as differences in names or greetings. Yet, except for one case where the Swiss name was misspelled, these mistakes happened only in replies to the minority candidates. Furthermore, it becomes evident that employers often make more of an effort and are more enthusiastic in their contact with majority candidates, even if the final outcomes recorded in the testing are the same. While these differences are likely to be unconscious, 
the final case was the most blatant in openly stating his preference for a young Swiss candidate ("I also like your age and your origin").

\section{Discussion}

Results from correspondence tests show a compelling way of portraying "clear and convincing evidence" (Fix and Struyk 1993) of discrimination. They can be understood intuitively, even for a lay audience. Yet, while they aim to quantify discrimination in the labour market, they address only one specific point in the hiring process. By reporting only the final outcome of the application procedure, invitation or rejection, correspondence test results fail to provide a more nuanced picture.

While Heckman and Siegelman have briefly acknowledged that supplemental data such as waiting times for an interview could be "enlightening and useful in illuminating potential causes of discriminatory treatment" $(1993,193)$, they do not discuss the issue further. However, it could be argued that the unobserved differences in employers' responses in correspondence tests are similar to their critique about unobserved differences for candidates. The findings presented in this paper show that the binary presentation of results (job interview: yes/no) can hide bias and subtle discrimination. The results further suggest that even if candidates experienced equal outcomes in the first stage of the application process, they might still face disadvantage in the second stage. Applicants who experienced subtle discrimination, might (unknowingly) go into a job interview with a disadvantage compared to the other applicant. Discrimination is therefore likely to be higher when candidates proceed to the actual job interview. These so far largely unobserved biases are important as they could predict a higher cumulative discrimination rate when it comes to actual job offers at the end of the application process.

Even though correspondence tests target a very specific moment in the hiring process, the examples presented above show that there are several ways in which employers can resort to discriminatory treatment, both intentionally or unconsciously. While the binary outcome of an application (invited: yes/no) is the main focus of correspondence tests, the previous discussion has shown that subtle discrimination also occurs with respect to response time or in content of the responses. Going back to the definition by Van Laer and Janssens (2011), we can observe that the instances of subtle discrimination are not easily recognized and can be ambiguous - they become visible only when email responses are compared side by side, they are in many cases unintentional and unconscious, and they are entrenched in every day interaction, such as responding to an email. Yet, while these subtle forms of discrimination might be unintentional and unconscious, over time these small disadvantages can become

$7 \quad$ Original German quote: «Natürlich [gefällt mir] auch, und das wissen Sie wahrscheinlich selbst zu gut, Ihr Alter und die Herkunft.» 
cumulative. As Blank et al. (2004) have shown, cumulative effects of discriminatory treatment can occur "throughout the stages within a domain, across domains, across individual lifetimes, and even across generations" (Blank et al. 2004, 11). They argue that candidates who anticipate discriminatory treatment can be discouraged from even trying to obtain skills or apply for certain positions.

\section{Conclusion}

As this paper has shown by using data from a recent correspondence test in Switzerland, discrimination also occurs on the Swiss labour market, even if the call back ratio is quite low with 1.48 (sales) and 1.12 (electricians) on the occupation level, low compared to results from other correspondence tests, in as much as these numbers can be compared. As the timing and content of the messages analysed above has shown, even if cases are reported as having an equal outcome in the correspondence test results, there can still be different treatment with regard to the timing and the wording of responses. This is the case in the ILO studies which were called "equal but different treatment" or in Hanson et al. (2011) "subtle discrimination". Incidences of subtle discrimination in the hiring procedure can be considered "to represent a different dimension of discrimination that is more difficult to uncover" (Hanson et al. 2011, 283). As Pager et al. observed, "It was only through side-byside comparisons of our testers' experiences that patterns of subtle but consistent differential treatment were revealed" $(2009,793)$. This was also observed in the Swiss results. While the evidence of correspondence tests is indeed "clear and convincing", it represents only the tip of the iceberg. Since most correspondence tests today are conducted by email, researchers have a lot of material at their disposal to analyse these instances of subtle discrimination in responses, and it would be interesting to see more discussion of these materials. In this vein, Crabtree (2018) suggests an automated analysis of these instances of subtle discrimination for large$\mathrm{N}$ correspondence tests.

As correspondence tests are often criticised for looking at only a very specific moment in the hiring process, that is, whether an applicant is invited for an interview or not, the material provided in emails or potentially also in mobile phone messages, can stress this point a little by looking not only at the final decision but also at some of the underlying mechanisms. Coupled with work from social psychologists, the findings suggest that discrimination not only occurs regarding whether or not applicants are invited for an interview, but also with resepct to how long they have to wait for a reply or how they are treated by a potential employer. Many of the observed instances of subtle discrimination are probably unintentional and unconscious (e.g. misspelled names or different greetings), yet others have shown a clear preferential taste for the majority candidate. While it is of course still pos- 
sible that employers hire applicants that experienced subtle discrimination in the previous stage, expected discrimination could also prevent candidates from applying, for example in the wording of the vacancy. Taken together, the latter incidences of subtle discrimination only add to other observed workplace incivility (Krings et al. 2014) show that discrimination can accumulate and that even seemingly minor incidences can build up in the long run.

\section{References}

Aigner, Dennis J. and Glen G. Cain. 1977. Statistical Theories of Discrimination in Labor Markets. Industrial and Labor Relations Review 30(2): 175-187.

Arrijn, Peter, Serge Feld, and André Nayer. 1998. Discrimination in Access to Employment on Grounds of Foreign Origin: The Case of Belgium. Geneva: International Labour Office, Conditions of Work Branch.

Arrow, Kenneth J. 1973. The Theory of Discrimination. Pp. 15-42 in Discrimination in Labor Markets, edited by Orley Ashonfelter and Albert Rees. Princeton: Princeton University Press.

Attström, Karin. 2007. Discrimination Against Native Swedes of Immigrant Origin in Access to Employment. Geneva: International Labor Organization.

Becker, Gary S. 1957. The Economics of Discrimination (2 $2^{\text {nd }}$ ed.). Chicago: University of Chicago Press.

Bendick Jr., Marc. 1996. Discrimination Against Racial-Ethnic Minorities in Access to Employment in the United States: Empirical Findings From Situation Testing. Employment Department, International Labour Office.

Bendick Jr., Marc, Charles W. Jackson, Victor A. Reinoso, and Laura E. Hodges. 1991. Discrimination Against Latino Job Applicants: A Controlled Experiment. Human Resource Management 30(4): 469-484.

Bendick Jr., Marc, Rekha Eanni Rodriguez, and Sarumathi Jayaraman. 2010. Employment Discrimination in Upscale Restaurants: Evidence From Matched Pair Testing. The Social Science Journal 47(4): 802-818.

Bertrand, Marianne and Esther Duflo. 2017. Field Experiments on Discrimination. Pp. 309-393 in Handbook of Economic Field Experiments (Vol. 1), edited by Abhijit Vinayak Banerjee and Esther Duflo. Amsterdam/Oxford: Elsevier.

Blank, Rebecca. M., Marilyn Dabady, and Constance F. Citro (eds.). 2004. Measuring Racial Discrimination. Washington, D. C.: National Academies Press.

Bovenkerk, Frank, Mitzi J.I. Gras, Dhurender Ramsoedh, M. Dankoor, and A. Havelaar. 1995. Discrimination Against Migrant Workers and Ethnic Minorities in Access to Employment in the Netherlands. Geneva: International Labour Organisation (ILO).

Cediey, Eric and Fabrice Foroni. 2008. Discrimination in Access to Employment on Grounds of Foreign Origin in France: A National Survey of Discrimination Based on the Testing Methodology of the International Labour Office (Vol. 85E). Geneva: International Labor Organisation (ILO).

Crabtree, Charles. 2018. An Introduction to Conducting Email Audit Studies. Pp. 103-117 in Audit Studies: Behind the Scenes With Theory, Method, and Nuance, edited by S. Michael Gaddis. Cham: Springer.

Daniel, William Wentworth. 1968. Racial Discrimination in England: Based on the PEP Report (Vol. 1084). Middlesex: Penguin. 
Darity, William A. and Patrick L. Mason. 1998. Evidence on Discrimination in Employment: Codes of Color, Codes of Gender. Journal of Economic Perspectives 12(2): 63-90.

de Prada, Miguel Angel, W. Actis, C. Pereda, and R. Perez Molina. 1995. Labour Market Discrimination Against Migrant Workers in Spain (Vol. 9). Geneva: International Labour Office (ILO).

Drydakis, Nick and Minas Vlassis. 2010. Ethnic Discrimination in the Greek Labour Market: Occupational Access, Insurance Coverage and Wage Offers. The Manchester School 78(3): 201-218.

Fibbi, Rosita, Bülent Kaya, and Etienne Piguet. 2003. Le Passeport ou le Diplôme? Etude des Discriminations à l'Embauche des Jeunes Issus de la Migration. Neuchâtel: Forum Suisse pour l'Étude des Migrations et de la Population.

Fix, Michael and Raymond J. Struyk (eds.). 1993. Clear and Convincing Evidence: Measurement of Discrimination in America. Washington, D. C.: The Urban Institute Press.

Gaddis, S. Michael. 2015. Discrimination in the Credential Society: An Audit Study of Race and College Selectivity in the Labor Market. Social Forces 93(4): 1451-1479.

Ghumman, Sonia and Ann Marie Ryan. 2013. Not Welcome Here: Discrimination Towards Women Who Wear the Muslim Headscarf. Human Relations 66(5): 671-698.

Goldberg, Andreas, Dora Mourinho, and Ursula Kulke. 1995. Labour Market Discrimination Against Foreign Workers in Germany. Geneva: International Labour Office, Employment Department.

Hanson, Andrew, Zackary Hawley, and Aryn Taylor. 2011. Subtle Discrimination in the Rental Housing Market: Evidence From E-mail Correspondence With Landlords. Journal of Housing Economics 20(4): 276-284.

Heckman, James J. and Peter Siegelman. 1993. The Urban Institute Audit Studies: Their Methods and Findings. Pp. 187-258 in Clear and Convincing Evidence: Measurements of Discrimination in America, edited by Michael Fix and Raymond J. Struyk. Washington, D. C.: The Urban Institute Press.

Helbling, Marc. 2011. Why Swiss-Germans Dislike Germans. European Societies 13(1): 5-27.

Kaas, Leo and Christian Manger. 2012. Ethnic Discrimination in Germany's Labour Market: A Field Experiment. German Economic Review 13(1): 1-20.

Krings, Franciska, Claire Johnston, Steve Binggeli, and Christian Maggiori. 2014. Selective Incivility: Immigrant Groups Experience Subtle Workplace Discrimination at Different Rates. Cultural Diversity and Ethnic Minority Psychology 20(4): 491-498.

Lodder, LeeAnn, Scott McFarland, and Diana White. 2003. Racial Preference and Suburban Employment Opportunities. Chicago: Legal Assistance Foundation of Chicago.

Longchamp, Claude, Martina Imfeld, Stephan Tschöpe, Meike Müller, Philippe Rochat, and Johanna Schwab. 2014. Verbreitung und Entwicklung von Rassismus, Fremdenfreindlichkeit, Muslimfeindlichkeit und Judenfeindlichkeit - Schlussbericht zur Studie "Zusammenleben in der Schweiz 2010-2014». Bern: GfS, http://www.gfsbern.ch/de-ch/Detail/zusammenleben-in-der-schweiz-2010-2014 (08.12.2016).

Neumark, David. 2018. Experimental Research on Labor Market Discrimination. Journal of Economic Literature 56(3): 799-866.

Pager, Devah, Bart Bonikowski, and Bruce Western. 2009. Discrimination in a Low-Wage Labor Market: A Field Experiment. American Sociological Review 74(5): 777-799.

Pager, Devah and Hana Shepherd. 2008. The Sociology of Discrimination: Racial Discrimination in Employment, Housing, Credit, and Consumer Markets. Annual Review of Sociology 34(1): 181-209.

Phelps, Edmund S. 1972. The Statistical Theory of Racism and Sexism. The American Economic Review 62(4): 659-661.

Quillian, Lincoln, Devah Pager, Ole Hexel, and Arnfinn H. Midtbøen. 2017. Meta-Analysis of Field Experiments Shows No Change in Racial Discrimination in Hiring Over Time. Proceedings of the National Academy of Sciences 114(41): 10870-10875. 
Rapp, Carolin. 2015. More Diversity, Less Tolerance? The Effect of Type of Cultural Diversity on the Erosion of Tolerance in Swiss Municipalities. Ethnic and Racial Studies 38(10): 1779-1797.

Raymann, Ursula. 2003. Meinungen und Einstellungen gegenüber AusländerInnen in der Schweiz. Zürich: GfS-Forschungsinstitut.

Reskin, Barbara. F. 2003. Including Mechanisms in Our Models of Ascriptive Inequality: 2002 Presidential Address. American Sociological Review 68(1): 1-21.

Riach, Peter A. and Judith Rich. 2002. Field Experiments of Discrimination in the Market Place. The Economic Journal 112(483): F480-F518.

Rich, Judith. 2014. What Do Field Experiments of Discrimination in Markets Tell Us? A Meta Analysis of Studies Conducted Since 2000. IZA Discussion Paper 8584. http://ftp.iza.org/dp8584.pdf (19.09.2018).

Rowe, Mary P. 1990. Barriers to Equality: The Power of Subtle Discrimination to Maintain Unequal Opportunity. Employee Responsibilities and Rights Journal 3(2): 153-163.

Ruedin, Didier, Gianni D’Amato, Nicole Wichmann, and Marco Pecoraro. 2013. Migrationsängste der Schweizer Bevölkerung. Neuchâtel: Swiss Forum for Migration and Population Studies (SFM).

Van Laer, Koen and Maddy Janssens. 2011. Ethnic Minority Professionals' Experiences with Subtle Discrimination in the Workplace. Human Relations 64(9): 1203-1227.

Weichselbaumer, Doris. 2016. Discrimination Against Migrant Job Applicants in Austria: An Experimental Study. German Economic Review 18(2): 237-265.

Zschirnt, Eva. 2019. Evidence of Hiring Discrimination against the Second Generation: Results from a Correspondence Test in the Swiss Labour Market. Journal of International Migration and Integration (Online first) 1-23.

Zschirnt, Eva. 2016. Measuring Hiring Discrimination - A History of Field Experiments in Discrimination Research. NCCR on the Move Working Papers, 7. https://nccr-onthemove.ch/publications/measuring-hiring-discrimination-a-history-of-field-experiments-in-discrimination-research/ (02.06.2016).

Zschirnt, Eva and Didier Ruedin. 2016. Ethnic Discrimination in Hiring Decisions: A Meta-Analysis of Correspondence Tests 1990-2015. Journal of Ethnic and Migration Studies 42(7): 1115-1134. 